\title{
AXIOLOGICAL SOURCES OF SOCIAL ORDER ACCORDING TO PAWEŁ WŁODKOWIC
}

ABSTRACT The paper focuses mainly on the doctrine concerning the approach of the Christian state towards pagans which described the practice of respecting the values that regulate social relations, and came as a result of the lifestyle of the society. It discusses the approach of Paweł Włodkowic, the rector of the Kraków Academy, who became famous for a speech given at the Council of Constance in 1415, and was a distinguished representative of this current of thought. Using theological and evangelical inspiration and legal knowledge, Włodkowic pointed to the effectiveness of practising the rules of spiritual life in social life. It allowed for the definition and recognition of the level of dialogue, understanding and compromise. Tradition, which in itself encapsulates consistency, is an important element of cultural and religious transfer. For it to occur in society in practice, it requires reception in the form of the normalisation and substantiation of its existence.

Keywords: Paweł Włodkowic, the Polish-Teutonic conflict, human dignity, tolerance, Jagiellonian model of the state, Council of Constance 
Btą, któremu się nie przeciwstawia, otrzymuje aprobate, a prawda, której się nie broni, zostaje zwyciężona.

(An error which is not resisted is approved;

A truth which is not defended is suppressed)

Paweł Włodkowic

\section{EUROPEAN HERITAGE}

The issue of whether to refer to the historical roots of Europe, and therefore also to Christianity and the Christianitas cultural circle, is currently perceived as problematic. This may be due to the different dynamics of change in Eastern and Western Europe, the result of religious divisions experienced over the centuries. From the $12^{\text {th }}$ century onwards, the persecution or exclusion of representatives of different religions, for instance the expulsion of Jews from France and Spain, was a recurring occurrence in Western Europe. Eastern Europe, on the other hand, was generally characterised by peaceful coexistence in areas inhabited by diverse cultures. In later years social relations would undergo change due to the influence of social processes which were the result of revolution and the imposition of new political systems. The model implemented in Central-Eastern Europe, especially in the $15^{\text {th }}-17^{\text {th }}$ centuries, may be more familiar to Europeans. It was also based on the Western model, but, in its particular context and distinctive social conditions, it was transformed into a new quality, which would be far more acceptable today. This quality is connected with the return to universal values which safeguard human dignity and rights.

Cultural heritage, an important building block of human dignity, shapes the feeling of freedom which respects the law, morals and culture, love and solidarity with others. It is one of the fundamental elements of the durability of the state and of national ties. Great energy lies in the Central-Eastern European culture of old, in the Republic of Poland, the energy which may still fuel morals, styles, literary genres and language, which may shape moral norms, especially in difficult times. The practice of tolerance in this region, here, has undoubtedly had an impact on the development of European culture and culture in general. Polish political culture, reformist thought and most of all the practical functioning of the Polish state constituted a "state without stakes" in the $15^{\text {th }}-17^{\text {th }}$ centuries, which greatly influenced the formation of the idea of tolerance.

Among other goals, the aim of science is to present cultural and intellectual heritage while maintaining the continuity of research on the achievements of past centuries. It is therefore important to discover the tradition of socio-political and theological thought formulated by such exceptional Poles as Pawel Włodkowic, at a time when modern political doctrines were gradually taking shape and when modern ways of defining the law and state were being determined. This practice aids in the expansion of the perspective and scope of thought concerning tradition and the difficult task of restoring that which 
has been forgotten or lost, in the context of understanding the contemporary trends which shape social life.

The twilight of the Middle Ages was a time of great importance in terms of its effect on the thought, culture and politics of that period. The time between the Middle Ages and Modernity was a period of great change, characterised by the first signs of modernity. At the time Europe was experiencing political turmoil, the continent was split into small states and principalities and religiously divided into Orthodoxy (East-West Schism) and Catholicism, which was itself divided due to the unstable and scandalous situation in the papacy, whose authority had to be rebuilt after the so-called Western Schism (cf. WeSOŁOWSKA 1997: 25-27).

In the European social reality of the time, it was important to call on the heterogeneous experience of the Polish society, characterised by a religiously, ethnically, culturally and linguistically rich and diverse structure. This type of society was undoubtedly something different and new in comparison to Western Europe, with its goal of building monolithic social structures governed by absolute monarchy. The prevailing mindset and social restrictions of the time usually resulted in society being defined as a political/religious organism rooted in religious unity (cf. KRACIK 1993: 66).

Towards the end of the Middle Ages, Central-Eastern Europe possessed the cultural foundations necessary for dialogue which would build the future of a heterogeneous European society based on a strong but open identity, a future based on responsible participation, resulting in a more dynamic civil society, which would justify the rule of tolerance on the basis of the pragmatism of the experience of past epochs. The phenomenon of Polish culture during the Jagiellonian Era was a result of the fact that it was primarily a matter of the spirit, that is the creation of values which cannot be converted to material goods. The ideas which emerged at the time were a product of the need to appreciate those traits of human personality which make it possible to consider man a being more perfect than other beings. In other nations this often resulted in the need of achieving a sense of belonging to a society which cherishes the ideals of freedom and justice, and appreciates human dignity or tolerance (cf. SAMSONOwiCZ 2003: 445-454).

This very image of Europe was experienced by the scientific minds who, through studies conducted at the universities of the time, which were spiritual and intellectual centres of exchange of knowledge, thought and experience, benefited from the opportunity of discovering the diversity of a world which was gradually becoming more familiar. The Kraków Academy, founded in 1364 by Casimir III the Great, contributed to the creation of an intellectual base in the form of theologians, lawyers and moralists - specialists who were to serve the state in the creation of a suitable policy towards the papacy, empire and neighbouring countries (cf. SwIEŻAWSKI 1987: 135, also cf. FiJA£EK 1900).

The founding of the Jagiellonian University was also the birth of theoretical science in Poland, from which materials were drawn for the practical defence of the interests of the Polish state during the Council of Basel and the Council of Constance. As a result, the most distinguished representatives of the Kraków Academy were not only theoreticians, but practical theologians (cf. MiCHALSKI 1997: 113-122). A practical approach, 
directed at the good of society and state (cf. MACIOŁEK 2011:71), became the convention which defined and shaped the general approach to learning of the entire university. Another highly important idea, which served as inspiration for the majority of the currents of thought of the time, was the idea of universalism. With the historical formation of the European community, Christianity should become Republica Christiana, under the leadership of two universal powers: the Pope and the Emperor. In theory this concerned universalism in reference to the entire world, but in practice this idea was connected with Europe, understood as a historical community associated with Christianity (cf. HALECKI 2002: 140).

The doctrine concerning the approach of the Christian state towards pagans, which opposed Western views and was gradually developed in the $15^{\text {th }}$ century in Poland, described the practice of respecting the values that regulate social relations, which was the result of the lifestyle of the society. Paweł Włodkowic, the rector of the Kraków Academy who became famous for a speech given at the Council of Constance in 1415, was a distinguished representative of this current of thought.

\section{THE MASTER - PAWEE}

Paweł Włodkowic, a professor, theologian, lawyer and diplomat, was born in 1370 in the village Brudzeń near Dobrzyń nad Wisłą, and passed away in Kraków towards the end of 1435 . He is considered one of the most vibrant and outstanding figures of the Jagiellonian Era (cf. NiesioŁowski 1935(a): 153). He studied not only in Prague, where he obtained the titles of Master of Liberal Sciences and Bachelor of Canon Law, but also in Padua, where he obtained the title of Bachelor of Decrees (canon law). In Padua he was a student of an exceptional lawyer, master Francesco Zabarella, the Cardinal of Florence, with whom Włodkowic developed a strong bond and whose views he would later quote in his work. ${ }^{1}$ Upon returning to Poland in approximately 1411 , he obtained a PhD in Law and began to teach law at the University of Kraków. He was rector in the years 1414-1415, and after 1418 vice-rector of this university. When King Władysław II Jagiełlo ordained that the dispute between the Polish state and the Order of the Teutonic Knights be moved to an international level, Włodkowic, who acted as envoy and was one of the king's ambassadors, took part in the proceedings of the Council of Constance in the years 1415-1418.

Three of the most important pieces of writing which came into being during the Council, Saevientibus (1415), Opinio Ostiensis (1415), Ad aperiendam (1416), outline, in an orderly manner, the rules of coexistence with non-Christians and pagans and the ways of proclaiming the gospel among them. Włodkowic, who wanted to demonstrate the universality of his views, touched upon the issue of the Pope's and Emperor's competences in terms of the power of man over man, the relation between papal power and

This sentence would usually begin with the words: „Pan mój Franciszek kardynał florencki...” Cf. among other titles QUONIAM II: 347, 362. 
secular power, the legal situation of the believers and non-Christian subjects, the attitude of Christians towards religious dissenters and the attitude of Christian states towards those who are non-Christian or pagan (cf. DyL 1990: 68-73).

His excellent legal and theological preparation, intellectual abilities and his status of scholar, professor and university rector, granted Włodkowic access to the diplomatic and political spheres of the kingdom in terms of both Polish and European affairs. His abilities also allowed him to constantly develop and improve his views concerning broadly-understood reality. His erudition, synthetic mind and diplomatic intuition gave rise to treatises, epistles, legal conclusions, supplications or maxims which surpassed similar texts from that age in their form and content. Włodkowic's writings were precise lectures of a clear structure and the argumentation contained within them was always convincing and very rich (cf. WIELGUS 1996: 12-13; WESOŁOWSKA 1998: 5-18). What is more, the earliest political papers authored by Włodkowic, which deal with social issues considered important at the time, are evidence of a high standard of science and civilisation and testify to the nobility and superb moral stance of Włodkowic himself and the environment in general (TARNOwSKI 2000: 22-23). Additionally, his use of "arguments on natural freedom, historical laws and the political subjectivity of nations, striking in their intellectual maturity and moral standards, served as a calling card with which Polish politics could oppose $15^{\text {th }}$-century Europe." (EKes 2010: 68-69)

The theological and political thought which was materialising at the time created the foundation of the Jagiellonian model of the state and the Jagiellonian model of that part of Europe, which was implemented in the Republic of Poland, the Czech Republic, Hungary and Bulgaria during the reign of the Jagiellonian dynasty. The values cited by Paweł Włodkowic, and the discussion concerning the need for religious tolerance, emerged in the $15^{\text {th }}$ century in the context of abuse and injustice committed by the Order of the Teutonic Knights in the Republic of Poland - under the guise of religious motives and the need to evangelise the pagans, the Order did great harm not only to pagans, but also to Christians. Paweł Włodkowic was decidedly against this treatment and invoked universal human rights, arising from the Scriptures and natural law and concerning the scope of the power of secular rulers and the clergy, the rulers' approach towards nonbelievers and believers, and the believers approach towards pagans. This was clearly a statement on tolerance which went beyond religious tolerance and demonstrated a type of social order characterised by a humanistic stance resulting from a sense of respect towards people and the organisation of national laws. In this manner Włodkowic became a precursor of ideas which would emerge in Europe in the $16^{\text {th }}$-century or later. ${ }^{2}$

It appears that Włodkowic's social experience, supported by his legal and theological education, and the influence of his professor and master from Padua, Francesco

The degree of originality of the views presented by Włodkowic is being discussed by historians. There are contrasting views; those which claim that Włodkowic only represented his predecessors and did not develop their ideas and those which highlight his originality and the modernity of his argumentation. Cf. MACIOŁEK 2011: 69-79. 
Zabarella, a representative of the so-called "tolerant line," resulted in the fact that his doctrine, presented at the Council of Constance, referred to the need of creating order in social relations based on the law of God and natural law. This explained and justified social relations based on the commandments contained in the Decalogue, which was considered the source of the generally recognised moral law (cf. SWIEŻAWSKI 1987: 135). This concerned both the relations between Christians and the stance of individual Christians towards religious dissenters or Christian countries towards non-Christian countries. This message was certainly considered novel by his listeners, both his supporters and opponents.

During the time when Europe was still considered Chrstianitas but was gradually assuming its new form, councils were by far the most important and largest opinionforming and legislative type of assembly. They could alter the form and nature of social life for a period of time and determine the direction of cultural and moral changes. The Council of Constance, considered the largest international gathering until the beginning of the $20^{\text {th }}$ century, was no different. Even towards the end of the $19^{\text {th }}$ century it was considered the greatest national congress which the world had ever seen. Its attendees hailed from all walks of life: cardinals, patriarchs, hundreds of bishops and archbishops, princes, representatives of monarchs and the representatives of cities and universities (cf. EHRLICH 1968: XXI). During its proceedings, the council brought up the issue of the so-called West Schism, which began in 1378 and consisted in the simultaneous recognition of three different popes: Gregory XII, Benedict XIII and John XXIII. Another issue which, at the time, was particularly important to the Church, were the effects brought about by the statements given by John Wycliffe and Jan Hus, considered not only a threat to the purity of the faith and ecclesial discipline, but also a violation of the social order. The need for reformation, which could not be carried out by the popes since they were involved in the conflicting interests of the countries which supported them, accelerated the development of the concept of conciliarism, an ecclesial orientation characterised by reformist and democratic tendencies in the Church which recognised the superiority of the Council over the Pope. ${ }^{3}$ The Council of Constance was home to a creative, highly intellectual environment, which managed to speed up the necessary reforms of the Church and effectively take care of the most important problems of the socio-religious life of the continent. Włodkowic, who highlighted "the primacy of ethics over short-distance expediency," stood out in this environment for his exceptional political sense (NIESIOŁOWSKI 1935(b): 775).

Włodkowic's greatness was based on the fact that he did not merely refer to the experience of injustice, ambition and political interests, but also highlighted the diversity of spiritual attitudes resulting from the misinterpretation or ill will in the imple-

The council, as a body of control and a buffer against the misuse of power, stands above the pope only in specific exceptional situations (moderate conciliarism) or fundamentally and universally (radical conciliarism). This theory was based on the thesis that the entire Church and ecumenical council as its fullest representation are by their nature carriers of all forms of power, including that which during the normal functioning of the papacy is vested in the office of Peter. Cf. SCHATz 2004: 157-158; also: Baron/Pietras 2003. 
mentation of intentional actions related to the practice of preaching the gospel, conversion and religious life. Włodkowic's genius manifested itself in his use of language, the wording employed in his writings, which would affect and successfully defend the Polish national interest against the finest European minds of the time. In addition, his writings were in opposition to the prevailing beliefs of the preferred ideological stance at the time. On the one hand, they would highlight the unity of Christian nations based on Catholic universalism, on the other hand, they were against the measures which stemmed from evangelical roots and opposed the Order. This resulted in tension, because it required the clear support of the Council for one side of the conflict. Additionally, the Polish side expected the support of the European opinion and the imposing of sanctions as a result of the victory at the Battle of Grunwald. The sanctions could even have been the dismantling of the Order or its relocation to Turkish or Tatar borderlands, where the "shield of Christianity" was still needed (cf. NiesioŁowsKi 1935(b): 780-781).

Without limiting himself to only the Polish case, Włodkowic undertook other important problems in relation to the Council and the reform of the Church. In his speeches he criticised the hallmarks of simony in the form of giving benefits and expressed his support for conciliarism (cf. BRzostowski 1954: 43, also cf. FiJAŁEK 1900). Pope Martin V's approval of the nomination of King Władysław II Jagiełlo and Grand Duke Vytautas to the Apostolic Vicariate as vicars to the Eastern lands of Europe was an important effect of the works conducted by the Polish delegation with the participation of Paweł Włodkowic. Another event of great importance was the condemnation and imprisonment of John of Falkenberg, an advocate for the eradication of the Polish nation, who supported the Order of the Teutonic Knights. Ultimately, Falkenberg admitted he was mistaken and officially withdrew his slanderous remarks directed at Poland (cf. NiesioŁowski 1935(b): 782 ff.).

The Polish delegation at the council was one of the greatest to have ever taken part in such a gathering. From the very beginning the delegation actively participated in the proceedings of the council and was regarded with respect and admiration (cf. BRzostowsKI 1954: 43). The commission under Francesco Zabarella, appointed by the council and focusing on the relations between Poland and the Order of the Teutonic Knights, could not settle the Polish-Teutonic dispute because of the deception, bribery and hypocrisy represented by the Order of the Teutonic Knights. Moreover, the Teutonic Knights presented themselves as defenders of the faith and the Poles as a nation which supported pagans and barbarians in order to persuade the Council to support further activities of the Order in the East. This situation required a competent reaction on behalf of the Polish delegation. In his treatises written during the Council, which contained theoretical and legal justification exposing the lies and hypocrisy of the Order of the Teutonic Knights, Paweł Włodkowic based his investigation of the truth and defence of the Polish national interest on moral principles, because law and morality are connected in numerous ways and therefore related to one another (cf. SWIEŻAwSKI 1987: 135). Włodkowic, always referring to the truth, presented the universal foundations of his doctrine which could be defended in any part of the world where man lives in harmony with the truth. 
During the Council of Constance, the Polish delegation spoke in defence of the rights of pagans and schismatics, which, as in the case of Spanish thinkers defending the rights of Native Americans infringed by the conquistadors, despite apparent marginalisation, fulfilled an important role in the further spiritual fate of Europe. The opinions presented by the Polish members of the council set the country on a difficult path through pluralism and tolerance and towards social and political decisions such as, for instance, the passing of the Warsaw Confederation Act more than one hundred and fifty years later. However, the opposite path, a path of intolerance, leading through fanaticism and a lack of understanding of diversity, was also followed, which led to harrowing events such as the St. Bartholomew's Day Massacre. Therefore, every word in support of tolerance and the defence and appreciation of diversity was precious. Opponents of this approach, often succumbing to the pressure of political power, considered it a damnable heresy. This attitude led to the embarrassing period in European history when people were burned at the stake, inquisitorial processes intensified, fratricidal religious wars were waged and the superiority of ideology over truth was argued through the practice of torture. In this context, the activity of Paweł Włodkowic, a spokesman for universal values, an advocate of truth and a defender of legitimate rights, becomes all-important for the practice of social life, especially in Central-Eastern Europe (cf. SWIEŻAWSKI 1987: 196-197).

The Polish-Teutonic conflict was one of the primary topics of concern for Polish diplomacy during several decades of the $15^{\text {th }}$ century (cf. GRAFF 2010: 9). The first systematised reactions to the Teutonic problem which emerged before the year 1410 were connected with the environment of the University of Kraków. In his statement on the subject, Stanisław of Skarbimierz attempted to systematise the rules of the war and the position of Poland in respect to Teutonic aggression. Basing his assertions on the existing norms of canon and natural law which were in force at the time, Stanisław defined the concept of a just war in a clear manner and he defined its admissibility and the consequences of waging this type of war. In addition, he described the legal consequences of particular approaches towards pagan states (BARYCZ 1958: 120). Paweł Włodkowic continued to develop Stanisław's thoughts with the inclusion of the principles of Roman law. Many authors believe this to be the beginning of the modern Polish school of international relations, which was more than one hundred years ahead of the classical theory of the law of nations. This historical universalism, which is so strongly supported by Paweł Włodkowic's writings, is evident in his thoughts on law, man, social relations in the context of justice and the conformity of human life with the natural law according to the Bible.

The source of Włodkowic's diplomatic, journalistic or scientific/cognitive activities focused around the Teutonic issue was deeply rooted in the author's personal experience of injustice carried out by the Order supposedly in the name of love and in the interest of religion. Włodkowic devoted much of his life to exposing and combating the cruel practices employed by the Order, of which he himself was a witness. Therefore, Włodkowic considered the need to point out the great threat that the Order was not only a theoretical religious and political problem, but an important 
issue affecting the sphere of social justice and human dignity in practice (cf. BARYCZ 1958: 121).

In his works, Włodkowic comments on the issues described in the texts in an interesting and competent manner that was deeply rooted in theological and legal knowledge. Facts that relate to the ethics of social life are important in the context of the discussed issues. In Teutonic writings of a doctrinal and polemic nature, for instance those of Jan Frebach or John of Falkenberg, Włodkowic saw not only short-term political goals, but also errors of a moral and legal nature (cf. SwIEŻAWSKI 1987: 251-252), especially since appealing to falsified facts and manipulated views posed a real threat to Polish national interests and the opinion of contemporary Europe about Poland ${ }^{4}$ Consequently, it was important to demonstrate that the real aim of the political spokesmen of the Order was to convince Christian Europe that the Polish people ought to be eradicated.

In an attempt to expose the real nature of the Order of the Teutonic Knights to the representatives of Western Europe, Włodkowic presented only the facts concerning the activity of the Order for example by pointing to legal errors in the arguments presented by the Order. Moreover, Włodkowic's indubitable merit was that he was able to present the seemingly internal Polish-Teutonic dispute at the level of the general human struggle for fundamental values (cf. BRzostowski 1954: 101, also cf. CHŁOPOCKA 1993: 17), placing it in the realm of ethics and morals. In order to highlight the importance of the council in respect to this issue, he stressed that

because an error which is not resisted is approved, and a truth which is not defended is suppressed, because of this, with the aim of discrediting particular writings, erroneous not only in respect to law and morality, but even, as is evident at first glance, hostile towards the Catholic truth, created for the benefit of the Prussian Teutonic Knights against the king and people of the Kingdom of Poland. [...] The present council, taking place in Constance, was convened primarily in order to eradicate such errors and heresy (QUONIAM I: 216).

The fundamental ideas formulated by Paweł Włodkowic were connected with the defence of the Polish national interests and the position of the Polish king, which was threatened by the ideological manipulation of the Order of the Teutonic Knights. His speeches gained importance due to the fact that he acted as envoy and ambassador to the king (cf. Graff 2008: 201). The determination of the Polish delegation and Włodkowic's professional preparation built upon an excellent extensive doctrinal and legal knowledge allowed him to refer to the foundations of morality in an appropriate manner. He was aware of the difficulty of the task set out before him. The possibility of choosing two paths: the doctrinal (processus doctrinalis) and the judicial (processus

4 In order to falsify documents, the Teutonic Knights used their own specialists and were even assisted by officials from the papal and imperial offices. One of the most common forms of manipulation was the use of a transumpt, a document which contained a copy of a different false document and whose validity could not be confirmed or whose confirmation was not desirable. In this manner the Order falsified documents that, for instance, gave them certain privileges. Cf. EHRLICH 1968: XVII-XVIII. 
iudicialis) highlighted this difficulty and the complexity of his role as a lawyer, attorney, envoy to the king, scholar and university representative, clergyman and official. He did not consider his function representative, but instead chose to put great effort into his speeches, realising the importance of the congregation before which he spoke. To Włodkowic this was not a typical judicial case, but a fight for principles (cf. BRzostowski 1954: 51) and so he finally opted for the doctrinal path. However, the difficulty of the task was exacerbated by the fact that he attempted to defend Christianity from the Order which itself acted in the name of the expansion and defence of religion (cf. EHRLICH 1968: XXII-XXIII). Only a man of substantial intellect and sensitive personality could put his broad knowledge to use, link it accordingly with religious values and social morality and present this in writing as generally applicable elements of international law. Włodkowic's writings contained a requirement of religious tolerance presented primarily in the axiological space since the practice of tolerance allows for building and preserving essential human values (cf. JASUDOWICZ 1994-1995: 49).

In the context of Włodkowic's writings, it was not only the circumstances of their creation but also their addressees that were of noteworthy importance. His manner of argumentation, the cited sources and unambiguous conclusions point to the practical nature of the texts, a result of Włodkowic's social and political experience and the internal and external conditions of the Republic of Poland at the time. It is worth noting that the scholar from Kraków did not limit the scope of his work to the Polish situation only. Using his own method, referencing fundamental sources and referring only to the most esteemed moral and scientific authority figures of the time, he created scientific, legal and moral bases for the functioning of the society whose coexistence is based on mutual respect, on the moral system which protects human dignity, on the law, which - when respected - allows for a peaceful life, and on social justice, which defines the reasons for and the scope of social respect. He even went one step further and, on the basis of their relations with the Order of the Teutonic Knights, defined the behaviour and use of power of the wealthy, including the highest offices such as the papacy and the empire which controlled the social and political functioning of society.

When writing about the Teutonic Knights, particularly in his treatise Ad aperiendam, Włodkowic highlighted the fact that they committed rape and other forms of crime despite their allegiance to the Church and that they justified their actions by claiming that their activities were associated with the propagation of the faith and the importance of the Church. In Paweł Włodkowic's work, the humanistic conception of morality was also influenced by the patriotic/political background resulting from direct experience with the Order of Teutonic Knights (cf. OGONOwsKI 1997: 141-144). The situation was further complicated by the fact that both the empire and the papacy generally supported the religious activity of the Order. The Teutonic Knights were given privileges which strengthened their position, but in building their political power they would depart from the ideals of the gospel. Włodkowic's succinct and harsh description of the Order was sure to cause great commotion or even scandal. Włodkowic described the Teutonic Knights as a sect, as a Prussian heresy: 
although it is of course stated in what these brothers presented in court and in articles, in which they admit that their order was established in order to exterminate nonbelievers and claim their goods and countries, this, according to them, is what their current documents state: it must therefore be said that they propagate cruelty rather than love, severity rather than charity, harm rather than aid, which is erroneous in the Christian faith, incompatible with love towards God and man and the truth of the gospel. Consequently, it is obvious that they are no religious order, but, if I may draw such conclusions, that they are a mistaken sect which should not be tolerated in any way by the Church of God (AD APERIENDAM: 25-26).

\section{FUNDAMENTAL VALUES}

Referring to social rights, especially in the context of the unjust activities of the Teutonic Order, Włodkowic raises two highly important issues: respect towards human dignity and respect towards the law. These two arguments are drawn from the teachings of the Bible, which regulate the relationship of man to God and God to man. Włodkowic believes this to be the basis for establishing the correct kind of social relations, where every man has the right to his own identity and diversity, and societies and nations have the right to sovereignty and peace. In some way this serves as an analogy to the twofold way of argumentation of the doctrinal and judicial paths. Although it is not unequivocal, the method and the sources used by the author point to his excellent level of theological and legal knowledge. Some of these elements reveal a relationship contained in Włodkowic's writings - the relationship between tolerance as an interpersonal relation and human dignity, which constitutes the basis for the creation and preservation of this relationship (cf. Domański 1995: 19-30).

The biblical law of love becomes the basis of proof of the fact that every man has the right to respect and, in consequence, every man ought to be treated in a tolerant manner. The uniqueness of every individual and the dignity which goes with it was previously stressed by Stanisław of Skarbimierz in the following vivid simile from his sermon on just wars:

If Catholic rulers can use slingers, machines, bombards and so on in their just war, they can, working against injustice, most definitely use any man, since all men are the most dignified of beings in this world (KaZANIE: 131).

Włodkowic claims that, since all men were created by God and consequently share the same nature, human dignity requires not only respect but also love and life in friendship:

however, according to human nature, according to which man was created in the image and likeness of God, he ought to be loved according to the Lord's commandment [...] "We love our neighbours as we do ourselves only if we love them not for our own benefit, not for expected or given blessings, not for kinship or familial ties, but because they are also members 
of our nature"; a vulgar voice may comment on the word "members," stating that Jews and Saracens are our neighbours and therefore ought to be loved by us as we love ourselves, that that is what concerns us. And this is why laws allow us to associate with the nonbeliever and sit at the same table, so that we can use them (AD APERIENDAM: 26).

Additionally, Włodkowic frequently highlights the importance of the law of God and the interpersonal relations that result from it. He usually does this in a similar manner, for instance: "Believers and nonbelievers are our neighbours, there is no difference between the two." (OpINIO: 129; similarly: SaEvientibus: 59)

Since man, in contrast to other creatures, is a thinking being, this distinction highlights the special nature of human dignity and man's place in the world: "God himself made everything serve the thinking being for whom he created it." (SAEviEnTiBus: 12) Human dignity also requires freedom, as per the will of God, since "all men by nature were free." (SAEviEntibus: 13) Włodkowic's comments on the difference between the relationship of man and Christ and man and the Church are particularly interesting: "Although nonbelievers are not part of the Church's flock, all men are without a doubt Christ's sheep as a result of creation: 'I have other sheep that are not of this fold." (OpINIO: 120) To his contemporaries, this distinction may have been shocking, and yet he still refers to the opinion of Pope Innocent IV in this conclusion. This understanding of the term "neighbour" confirms Włodkowic's position as not only a supporter of religious tolerance but also of pluralism. His direct reference to the Saracens and all pagans as "neighbours" who ought to be loved suggests that his belief in this idea, presented in the text on the abolition of the privileges of the Teutonic Knights, was deeply held. Since he refers to the unity of man by nature both in terms of body and soul, this points to human dignity being associated with the dignity of a child of God. "One is required to treat the Saracens and pagans with the same amount of love, since not only their soul but also their body is human by nature." (Cf. AD videndUM: 179) Włodkowic does not equate concern for others solely with concern for one's own salvation, which was the primary idea of converting others to the faith. He perceives man as a whole, made up of soul and body, and he does not limit his perception of nonbelievers merely to a lack of wrongdoing. Włodkowic's understanding of the duty of love is directly based on that which appears in the Bible and in the teachings of the gospel, the duty of:

1) doing good: ,for love of one's neighbour does not do the evil work of expulsion, or (perpetrate) any other (evil), for charity does not behave itself unseemly and the right will does not perpetrate iniquity. This natural and divine law is immutable and thus can not be set aside even by the Pope, because its change implies sin. Hence it is also that by this law we are bound to help them in necessity, and to give alms";

2) forgiving: „since forgiveness is due to him if he were captive, especially where disturbance of the peace is not feared";

3) respecting ownership: „for the (same) reason for which we must not deprive peaceful pagans of their property, we must not deprive them of it heir native land and expel them"; 
4) inviolability, or even defence: „therefore the successor of Peter has to feed and defend them, therefore not to permit them to be attacked or hurt."

He justifies this by stating that "in the Christian religion [...] there is a gentleness and kindness, whose opposite is cruelty." He also notes that to understand these words differently is simply to sin (cf. AD VIDENDUM: 179-181).

The anthropology employed by Paweł Włodkowic was deeply rooted in Christianity and the tradition of the Latin civilisation. Man, created in the image and likeness of God, is inherently gifted with dignity and free will, which means that regardless of his background or social position, he constitutes a value in itself (cf. BIzoŃ 2008/2009: 170-180). As a lawyer, Włodkowic analysed the logic of the law in order to find bases for theological arguments which would allow for the identification and reveal of the mistake which contributed to the immoral practices employed by the Teutonic Knights under the guise of concern for the faith. Taking the law of God as a basis directed towards all people allowed for the opportunity to appeal to tolerance as a form of respect towards that law.

A characteristic feature of Włodkowic's humanism, which can be found in his writings but was still unheard of in the West at that time, was his highlighting of the dignity of every individual irrespective of faith and his condemnation of religious coercion. He believed that respect towards human dignity also applies to pagans and every form of coercion undermines human dignity (cf. GóRSKI 2007: 90). For instance, he claimed that religious dissenters (Jews and Muslims) and pagans have the right to be in control of their own states and freely practice their own religions within them. What is more, on the condition that their religious worship be practiced according to the norms of natural law, he acknowledged their right to their own form of worship even if they were to live in a Christian state. To quote Włodkowic himself: "if nonbelievers wish to live peacefully among Christians no harm should come to them or their possessions." (SAEVIEnTiBUS: 59.) Włodkowic based his argumentation on the Bible and the behavioural norms revealed by God, the teaching of Thomas Aquinas and Pope Innocent IV ${ }^{5}$ and the views of his master from Padua, Francesco Zabarella. Following in the footsteps of Thomas Aquinas, he claimed that no one ought to be forced to believe, but also that a faith once adopted should not be abandoned. He considered punishing someone for their crimes against God a form of piety rather than cruelty. Consequently, despite his tolerant stance towards nonbelievers, Włodkowic referred to heresy and heretics in a very strict manner, as in the case of Jan Hus and Jerome of Prague. He held the very daring theological view, which he expressed in his writings, that the theories which go against love, including loving one's neighbour, the most important law of the gospel, are the most dangerous, rather than those which go against the idea of God.

Innocent IV, Sinibaldo Fieschi born in approximately 1195 in Genoa, died on 7 December 1254 in Naples - pope in the period from 25 June 1243 to 7 December 1254. He was an exceptional representative of the current of thought related to the concept of natural law, according to which religious dissenters may live in countries organised according to their own internal rules. Cf. KośCielny 2013: 48. 
In terms of the literary activity of the $15^{\text {th }}$ century, there was a noticeable change in the nature of the texts written at the time and the style employed by the authors. Lengthy commentaries and voluminous summae were replaced with treatises on current ethical issues. This was most definitely the result of the changes which were taking place at the time, the creation of new cultural relations primarily connected with the development of universities. Treatises on ethics, an observable intellectual achievement of the intellectual circles which existed at the time, occupied an impressive place in the libraries that were gradually being constructed during this period. Important and pressing social issues connected with behaviour, ethics and morality also appeared in encyclopaedic works, poems or writings of an ascetic-religious nature. This was also related to the tendency to equate the nature of social relations in Christianity with evangelical morality. The severe and virtually ubiquitous moral and institutional crisis that affected the Church at the time was connected with the heritage passed on from previous times, and it was this crisis that forced people to make life changes on the one hand and, on the other, served as an announcement of upcoming religious splits, wars and persecution.

In the interpretation and evaluation of the present situation, one may note the use of the innate nature of natural law, which came from God because God inscribed it into the human conscience and mind although it was not sacred.This understanding and application of natural law could reveal conflicts both within the existing secular positive law and the church law created at the time. Representatives of this type of understanding of the law, including Włodkowic, perceived one of the main characteristics of natural law in the universal and certain belief that all men without question are of the same nature, that they are unified by having the same goal and, consequently, they should treat one another with respect. However, the commandments of natural law are not determined solely by religion and affect Christians, pagans, rulers and subjects equally. This $15^{\text {th }}$-century tendency related to the interpretation and usage of law was one of the basic elements of Włodkowic's argumentation (cf. SWIEŻAWSKI 1987: 293).

The social situation in Europe described above and the abuse on part of the Teutonic Knights in Poland led to legal-theological treatises by Paweł Włodkowic whose purpose was the search for justification in natural law, that is in "pre-Christian," universal morality (cf. SWIEŻAWSKI 1987: 83). Włodkowic's opinion that that which is correct is just, is important in the context of the dispute on the subject of justice taking place among theologians and lawyers. He defines correctness as the adequate and proper accustoming and harmonisation of two parties (cf. SwIEŻAwsKI 1987: 94). This led to the determination of the source of good and evil. In terms of this issue, Włodkowic was an adamant opponent of the theory of decisionism, which was preferred at the time and which stated that only the absolute and free decision of God means that a particular action may be considered morally good or evil. He perceived this view as a threat to the unwavering validity of the laws of nature (cf. SWIEŻAWSKI 1987: 119-120). Włodkowic limits the nature of his legal investigation to the legal order which indicates legal comprehension only within the sphere of juridical issues, which allows for the fullest understanding of the facts and their causes (cf. SWIEŻAWSKI 1987: 140). 
Natural law at that time was commonly accepted as the highest and most important of all laws and was the ultimate criterion in evaluating human activity. "The thinkers of the Middle Ages not only gave expression to this truth, but they also made it an integral part of the spiritual heritage of humanity, and this was their most glorious achievement." (SWIEŻAWSKI 1987: 143.) Włodkowic's assumption that the teachings of Christianity possess a value for every man and natural law - recognising such values as human life, freedom, justice and truth - must be in agreement with the positive law of God became a view which was repeatedly confirmed by history. It is worth noting that the exceptional status ascribed to natural law in the $15^{\text {th }}$ century is no longer noticeable or even ignored. (Cf. Rutowski 1985: 194.)

Paweł Włodkowic also warned about the usage of the law of God against natural law in the name of defending supposedly superior and endangered values, which was often used as an argument when attempting to defend or spread the faith by use of force or violence. Speaking in the name of the king and the law school of the University of Kraków, he used the words of Thomas Aquinas which stated that the law of God may never oppose natural law and not only does it not abolish that law, but it is based on it (cf. SwIEŻAWSKI 1987: 144-145).

The shaping of social relation in the Middle Ages was clearly influenced by thinkers who spoke of the importance of fundamental values. Theoreticians and experts from that period highlighted the importance of the influence of metaphysics and referring to natural law as the foundations which regulated social and international relations. Medieval adherents to the practice of referring to natural law were often supported by the lawyers and theologians of the time who represented the so-called "tolerant line" represented in the Church by, among others, Pope Innocent IV and Thomas Aquinas. However, little by little, natural law was theoretically and practically marginalised due to the weakening of tolerant tendencies. This situation was influenced by the supporters of radical theocracy who maintained that nonbelievers are not the legal owners of their land and thus may be converted by use of force (cf. SWIEŻaWsKi 1987: 239).

Christian anthropology not only had a general influence on the development of civilisation, but most of all it was gradually becoming the primary form of interpreting the Roman law which was in force during the first centuries of Christianity. One of the most important effects of the influence which was typical of the Christian natural law was the evolution of the term ius gentium - the law of nations. It was related to a number of statements typical for Christianity such as: all men are free by nature, created to live in harmony and peace, and material goods ought to be shared, which leads to different forms of co-ownership and the use of one's own goods to the benefit of one's neighbour. The term ius gentium evolved in response to slavery, which was the result of numerous wars and the thesis that private ownership is a necessity due to the influence of original sin on human nature. Created by Roman lawyers, the term encompassed slavery, laws of war, military occupation and a number of institutions which, from the point of view of the first Christians, were not strictly connected with the always good and always true natural law. Apart from the institutions created by man, the Christian 
idea of freedom emerged at the time - a true force which led to the abolition of slavery, which had a real impact on the shape of social relations (cf. HeRVAda 2013: 71-72).

Initially, ius gentium was most definitely understood as a part of natural law. However, interpretations gradually appeared which considered it the only positive law. This view greatly altered the nature of ius gentium since it resulted in the understanding of the law of nations as a law enforced by the ruler rather than a law embedded in the human conscience by God. Paweł Włodkowic disagreed with this type of evolution of the law of nations. He believed that the law of nations does not differ from natural law, which is common to man and animals, and, in a narrow sense, the law which identifies with ius gentium:

The law known as natural is common to us and other creatures. [...] The law of nations splits off from this law [...] That which was established by the natural mind among all people is abided by all nations and is known as the law of nations (SAEvientibus: 92).

In some statements Włodkowic refers to natural law as quasi-natural, in others he considers the law of nature a guardian of the law of nations. However, Włodkowic clearly believes that ius gentium is closely tied to natural law and relies upon it (cf. SWIEŻAWSKI 1987: 145-146).

It is worth noting that the views gradually taking shape in the Kraków law school during the $15^{\text {th }}$ century, which were to be so effectively employed during the Council of Constance, were an important element in the development of the legal culture of the time. This was of great importance in relation to the concept of the law of nations, ius gentium, whose inception is usually attributed to Francisco de Vitoria $\left(16^{\text {th }}\right.$ century) or Hugo Grotius ( $17^{\text {th }}$ century). As it was the source of ideas which directly or indirectly influenced the emergence of legal ideas in the modern period, the importance of the output of the legal environment in Kraków cannot be overemphasised. ${ }^{6}$ Ludwik Ehrlich states decidedly that Stanisław of Skarbimierz and Paweł Włodkowic created the concept of the law of nations understood as the law of international relations at the beginning of the $15^{\text {th }}$ century (cf. EHRLICH 1955: 77-79). Therefore, it appears that the Jagiellonian state, known for its tolerance, constructed this idea on the rich foundations of the achievements of the representatives of the Kraków law school who, in turn, included the social experience of the Polish nation in their work. It is worth noting that although the academic output of this period was and still is not always correctly evaluated and appreciated, as a theory and a foundation of international law it is of great, and not only European, importance (cf. SwIEŻAWSKI 1987: 147-148).

The 15-century legal and religious texts which accompanied the creation of Corpus iuris canonici were a rich source of knowledge on the organisation of social and mor-

6 Although Western sources do not mention it, one cannot exclude the influence of the Polish school of the law of nations on the formation of later, but considered first, concepts created by de Vitorio or Grotius. One could say that in this creative and inspiring though indirect and underappreciated way Włodkowic and the representatives of the Kraków school introduced the Polish theological and political thought into European culture. Cf. WOLEŃSKi 2010: 51. 
al issues. This was important when, during the strengthening of the papal monarchy, changes took place in the interpretation of canon law. This allowed for the introduction of changes, the organisation of Church life and reaching a state of social peace (cf. Swieżawski 1987: 152-153). Peace was already understood at that time not only in a negative sense as a lack of war, but also in its positive meaning as enriched by descriptive, normative and evaluative content. The view exhibited in recent years which states that peace as a fundamental value is realised not only through the elimination of wars, but also by giving it a positive meaning expressed in social justice and respect towards the dignity and freedom of the individual and equality before the law dates back to the Polish social (theological) thought of the $15^{\text {th }}$ century. It was first stated at that time that lasting peace may only be achieved through dialogue, tolerance and cooperation, and not by use of force (cf. MicHOwicz 1997: 42-44).

\section{RECEPTION OF THE HERITAGE OF JAGIELLONIAN EUROPE}

Although Włodkowic included theories and concepts in his works which had their sources in the Middle Ages and were rooted in the Medieval reality, his doctrine was also, to a large extent, based on the timeless values arising from the Bible and natural law. This is why their validity and universality is timeless. In the views of Paweł Włodkowic one can find not only a reflection of the religious and political relations in the Jagiellonian Poland of the time, but a depiction of the legal and political state of the Jagiellonian monarchy (cf. OGONOwSKI 1997: 141-144). Without a doubt Włodkowic's entire legal and diplomatic activity, which is also reflected in politics and ecclesiology, greatly influenced the development of views concerning the understanding of interpersonal and international relations (cf. DyL 1990: 68).

Paweł Włodkowic's doctrine is charged with moral and intellectual meaning. In response to the threat towards the social order of the time, Włodkowic referred to values which guarantee man respect for his dignity: society - the creation of just law, and in the context of international relations - peace and good neighbourly cooperation. The doctrine was based on the return to the Bible, natural law, life in truth and tolerance, that is the generally understood concept of humanism, which shapes man and influences social life based on universal values. These views are particularly important in relation to the integration processes currently taking place in Europe. The mutual relations between the legal system and moral experience in this case, in Paweł Włodkowic's doctrine, may help in the struggle for balance which is needed in the formation of society in a united Europe.

The possibility of coexistence in the socially diverse Poland required a constant motivation to accept, respect or, at the least, tolerate. The experience which characterised the Jagiellonian Era was rooted in simple interpersonal relations, respect towards the individual and dignity, which every person ought to respect and demand for themselves. Although this description seems excessively idealised, in practice the correct social relations were maintained, and not only for pragmatic reasons. 
In the world affected by the crisis of losing sight of one's own roots, the decline in the value of family, the weakening of the manifestations of interpersonal solidarity, the imposition of anthropology without God, the promotion of the "culture of death" and propagation of the privatisation of religion and the lack of a value system which would be an answer to the above problems, a new life based on values which give full and incredible meaning to human life is evident. A depiction of these values is always a depiction of God on the side of man, his greatest hopes, ambitions and dreams. In his analysis of the social situation in Europe, Jaime Mayor Oreja warns that the existing crisis is of a global nature and it will test not only the concepts and different aspects of social life, but also the basic institutions. The danger is the destruction of these institutions if the cultural and anthropological effects of the crisis are not taken into consideration beforehand. The essence of the answer to this crisis is to study it within an anthropological backdrop taking into account all of humanity with all of its important characteristics (cf. OREJA 2013: 63).

The social effects of the crisis in the spiritual realm are manifested in the form of powerlessness and discouragement in response to fears and dangers. This can be perceived in all spheres of social life including religious communities. This is why John Paul II urged residents of the old continent to attain renewal through the restoration of the evangelical value system and the construction of the future of Europe, the "European Spiritual Community," on its foundations (cf. Zenderowski 2003: 6). The Pope considered the understanding of the challenges posed by God to test man through events associated with his life as the modern task of the Church. He searched for the beginnings of European civilisation, finding that which constitutes its roots. He uncovered its strength in the past but also exposed its weaknesses; for instance, threats stemming from hostile political systems, totalitarianisms and ideologies which distort the importance of fundamental values. The Pope evaluated the situation in modern Europe and saw its crisis. By exposing its weaknesses, he highlighted the inability to cope with history, problems with the value system and visible disruptions in the relation between "to be" and "to own" - with the re-evaluation of "to own."

The way in which people communicate has always been essential in the shaping of the social order. Understanding the underlying mechanisms of community life facilitated the identification of the sources of social morality, which decided the quality of life and dialogue. In this context a new value of social life appeared - the need to compromise, which was always the result of searching for the same path with mutual respect towards core values and moral rules. Incorporating the experience of social reality in their research, scholars who studied this subject searched for ways of describing the mechanisms of collective life, the law which governs it and ways of respecting social morality. The understanding of social relations in Jagiellonian Poland led, in a natural manner, through compromise to tolerance, often limited by numerous regulations which protected the inviolability of the fundamental good. Pawel Włodkowic, using theological and evangelical inspiration and legal knowledge, pointed to the effectiveness of practising the rules of spiritual life in social life. It allowed for the definition and recognition of the level of dialogue, understanding and compromise. Tradition, which in itself 
encapsulates consistency, is an important element of cultural and religious transfer. For it to occur in society in practice, it requires reception in the form of the normalisation and substantiation of its existence.

Examples of the reception of Pawel Włodkowic's ideas can be found in many areas of John Paul II's teachings, public appearances, official documents and numerous letters. They indicate the need to continue the two-thousand-year-old tradition and its faithfulness in the task of maintaining the axiological order, renewing man, his relationship with God and building social order. Therefore, the point is the humanisation of public life (cf. NITECKI 2004: 119), for "bearing in mind the fruitfulness of Christianity in relation to European culture throughout the ages, the evangelical approach theoretical and practical - towards reality and man must be presented." (JoHN PAUL II 2006: 886.)

The postulate of respect towards human dignity can be realised in a just and sovereign society, which allows for fully experiencing one's identity and subjectivity. Relationships resulting from experiencing dignity personally should be based on responsibility for others and the realisation of the principle of solidarity in different contexts of social life, including the reality of a united Europe. On a religious plane such approaches lead to an ecumenical understanding of difference.

The historical heritage of the Republic of Poland co-creates European history even when it is forgotten or purposefully omitted. That is why modern Europe ought to be open to the riches of the cultural heritage of Central-Eastern Europe, the heritage of which it was deprived. It also appears that the duty of the inhabitants of this part of Europe is to present praiseworthy examples of service towards the ideals of freedom, tolerance, human dignity and the law of nations, for these values are timeless and their modernity lies in the fact that they must be constantly rediscovered.

Translated by Zuzanna Stawik

\section{REFERENCES}

Ad APERIENDAM: Paweł Włodkowic: "Ad aperiendam (1416), pars II," in: Ludwik Ehrlich (ed.): Pisma wybrane Pawta Wtodkowica. Vol. 3. Warszawa: Pax, 1969.

Ad videndum: Paweł Włodkowic: "Ad videndum (1421)," in: Ludwik Ehrlich (ed.): Pisma wybrane Pawta Wtodkowica. Vol. 3. Warszawa: Pax, 1969.

Baron, Arkadiusz; Pietras, Henryk (eds.) 2003: Dokumenty Soborów Powszechnych. Vol. 3. Konstancja Bazylea-Ferrara-Florencja-Rzym (1414-1445). (Źródła Myśli Teologicznej. 30.) Kraków: Wydawnictwo WAM.

BARYCZ, Henryk 1958: Alma Mater Jagellonica. Studia i szkice z przesztości Uniwersytetu Krakowskiego. Kraków: Wydawnictwo Literackie.

Bızoń, Michał 2008/2009: “Wojna sprawiedliwa w myśli Pawła Włodkowica," Pressje 16: 170180.

Brzostowski, Tadeusz 1954: Pawet Wtodkowic. Warszawa: Pax. 
ChŁopocka, Helena 1993: “Uwagi o tzw. 'Ostatnim słowie’ Pawła Włodkowica o zakonie krzyżackim,” Zapiski Historyczne 58(2-3): 7-25.

Domański, Juliusz 1995: "La tolleranza religiosa e la guerra giusta negli scritti di Stanislao di Scarbimiria e di Paolo Vladimiri," Odrodzenie i Reformacja w Polsce 39: 19-30.

DyL, Janusz 1990: "Dążenie do sprawiedliwości polskiego uczonego Pawła Włodkowica (ok. 1370-1435)," Communio 10(5): 68-85.

EHrLICH, Ludwik 1955: Polski wyktad prawa wojny XV wieku. Kazanie Stanistawa ze Skarbimierza De bellis iustis. Warszawa: Wydawnictwo Prawnicze.

Ehrlich, Ludwik 1968: "Przedmowa," in: Idem (ed.): Pisma wybrane Pawta Wtodkowica. Vol. 1. Warszawa: Pax.

Ekes, Janusz 2010: Ztota demokracja. (Biblioteka Myśli Politycznej. 71.) Kraków: Ośrodek Myśli Politycznej.

FIJAŁEK, Jan 1900: "O początkach i znaczeniu Uniwersytetu Krakowskiego w XIV/XV wieku," in: Ksiega pamiątkowa Uniwersytetu Lwowskiego ku uczczeniu pięćsetnej rocznicy fundacji jagiellońskiej Uniwersytetu Krakowskiego. Lwów: Senat Uniwersytetu Lwowskiego.

Górski, Artur 2007: Ku czemu Polska szta. Ed. Ewa Konstanty. Warszawa: Fronda.

GRAFF, Tomasz 2008: Episkopat monarchii jagiellonskiej w dobie soborów powszechnych XV wieku. Kraków: Wydawnictwo TN "Societas Vistulana."

Graff, Tomasz 2010: Kościót wobec konfliktu z zakonem krzyżackim w XV wieku. Studium z dziejów kultury politycznej polskiego episkopatu. Kraków: Księgarnia Akademicka.

HALECKI, Oskar 2002: Historia Europy - jej granice i podziaty. (Biblioteka Europy ŚrodkowoWschodniej. 1.) Transl. by Jan Maria Kłoczowski. Lublin: Instytut Europy ŚrodkowoWschodniej.

Hervada, Javier 2013: Historia prawa naturalnego. Transl. by Anna Dorabialska. Kraków: Wydawnictwo Petrus.

Jasudowicz, Tadeusz 1994-1995: "Zasada tolerancji religijnej w nauczaniu Pawła Włodkowica," Roczniki Nauk Spotecznych 22-23(1): 47-68.

John Paul II 2006: “Adhortacja apostolska Ecclesia in Europa," in: Idem: Dzieta zebrane. Vol. 2. Adhortacje. Kraków: Wydawnictwo M.

KaZAnie: "Kazanie mistrza Stanisława ze Skarbimierza, doktora prawa kanonicznego, o wojnach sprawiedliwych itd.," in: Ludwik Ehrlich: Polski wyktad prawa wojny XV wieku. Kazanie Stanistawa ze Skarbimierza De bellis iustis. Warszawa: Wydawnictwo Prawnicze, 1955.

Kościelny, Robert 2013: Przedmurze chrześcijaństwa. Czas królów elekcyjnych. (Kościół na Straży Polskiej Wolności. 2.) Kraków: Biały Kruk.

KRACIK,Jan 1993: “Tolerancja i nietolerancja w dziejach Kościoła. Starożytność i średniowiecze,” Znak 457: 66-75.

MacioŁeK, Michał M. 2011: “Różnorodność spojrzeń na stanowisko polskich myślicieli XV wieku wobec ważnych problemów Kościoła i państwa, in: Stanisław Janeczek, Rafał Charzyński, Michał Maciołek (eds.): Światopogladowe odniesienia filozofii polskiej. Lublin: Wydawnictwo KUL.

Michalski, Konstanty 1997: Filozofia wieków średnich. (Studia do Dziejów Wydziału Teologicznego Uniwersytetu Jagiellońskiego. 5.) Transl. by Kryspin Banko, Stanisław Rospond. Kraków: Instytut Teologiczny Księży Misjonarzy. 
Michowicz, Waldemar 1997: "Pokój jako przedmiot badań naukowych," in: Eugenia Anna Wesołowska (ed.): Pawet Wtodkowic - wspótczesne znaczenie poglądów i dokonań. Toruń: Wydawnictwo Adam Marszałek.

Niesiołowski, Andrzej 1935(a): "Paweł Włodkowic i jego doktryny na tle epoki. (Z okazji 500-lecia jego śmierci)," Przegląd Powszechny 4.

Niesiołowski, Andrzej 1935(b): “Testament Pawła Włodkowica," Verbum (Warszawa) 4.

Nitecki, Piotr 2004: “Orędzie nadziei dla Europy. Nad adhortacją apostolską 'Ecclesia in Europa”, in: Andrzej Brenk (ed.): Facere veritatem in caritate. Ksiega jubileuszowa ku czci księdza biskupa Pawta Sochy CM w 70 rocznice urodzin. Poznań: Pallotinum, pp. 113-121.

OGONowski, Zbigniew 1997: “Trzy postawy wobec tolerancji. Włodkowic - Modrzewski socynianie," Archiwum Historii Filozofii i Myśli Spotecznej 42: 141-149.

Opinio: Paweł Włodkowic: "Opinio Ostiensis (1415)," in: Ludwik Ehrlich (ed.): Pisma wybrane Pawta Wtodkowica. Vol. 1. Warszawa: Pax, 1968.

OREJA, Jaime Mayor? 2013: "A statement in the discussion: Świeckość - wartość czy zagrożenie," in: Rafał Budnik, Michał Góra (eds.): Chrześcijańskie oczekiwania wobec ksztattu Europy. Rola Kościoła w procesie integracji europejskiej. Gliwice: Wydawnictwo "Wokół nas."

Quoniam I: Paweł Włodkowic: "Quoniam error (1417), pars I," in: Ludwik Ehrlich (ed.): Pisma wybrane Pawta Wtodkowica. Vol. 2. Warszawa: Pax, 1966.

Quoniam II: Paweł Włodkowic: "Quoniam error (1417), pars II," in: Ludwik Ehrlich (ed.): Pisma wybrane Pawta Wtodkowica. Vol. 2. Warszawa: Pax, 1966.

Rutowski, Tadeusz 1985: "Filozoficzno-teologiczne poglądy Pawła Włodkowica. Na podstawie pism 'Saevientibus' i 'Opinio Ostiensis,' Studia Ptockie 13: 184-194.

Saevientibus: Paweł Włodkowic: "Saevientibus (1415)," in: Ludwik Ehrlich (ed.): Pisma wybrane Pawta Wtodkowica. Vol. 1. Warszawa: PAX, 1968.

SAmsonowicz, Henryk 2003: "Miejsce Polski w dialogu kultur," in: Stanisław Wilk (ed.): Chrześcijaństwo w dialogu kultur na ziemiach Rzeczypospolitej. Materiaty międzynarodowego kongresu, Lublin, 24-26 września 2002 r. Lublin: Wydawnictwo KUL.

Schatz, Klaus 2004: Prymat papieski. Od początków do wspótczesności. Transl. by Ewa Marszał, Jerzy Zakrzewski. Kraków: Wydawnictwo WAM.

SwiEżAwski, Stefan 1987: U źródet nowożytnej etyki. Filozofia moralna w Europie XV wieku. Kraków: Znak.

Tarnowski, Stanisław 2000: Pisarze polityczni XVI wieku. (Biblioteka Klasyki Polskiej Myśli Politycznej. 1.) Kraków: Ośrodek Myśli Politycznej and Księgarnia Akademicka.

WesoŁowska, Eugenia Anna (ed.) 1997: Pawet Wtodkowic - wspótczesne znaczenie poglądów i dokonań. Toruń: Wydawnictwo Adam Marszałek.

Wesołowska, Eugenia Anna 1998: "Paweł Włodkowic i jego poglądy," in: Eadem (ed.): Śladami Wtodkowica. Cztowiek, prawo, pokój. (Zeszyty Naukowe - Szkoła Wyższa im. Pawła Włodkowica w Płocku. 7.) Toruń: Wydawnictwo Adam Marszałek.

Wielgus, Stanisław 1996: Polska średniowieczna doktryna "ius gentium." Lublin: Redakcja Wydawnictw KUL.

WoleŃsKi, Jan 2010: “Średniowiecze," in: Jan Skoczyński, Jan Woleński: Historia filozofii polskiej. (Myśl Filozoficzna.) Kraków: Wydawnictwo WAM. 
Zenderowski, Radosław 2003: “Czym jest Europa? Kim są Europejczycy?” in: Sławomir

Sowiński, Radosław Zenderowski: Europa droga Kościoła. Jan Pawet II o Europie i europejskości. (Zrozumieć Europę.) Wrocław: Zakład Narodowy im. Ossolińskich.

Rev. Józef ŁUCYSZYN CM, is a Doctor of Theology specialising in the social doctrine of the Catholic Church. In the years 2009-2011 he was the Rector of the Theological Institute of Missionary Priests in Kraków, currently he holds the position of the Director of the Kraków's Province of the Company of the Daughters of Charity of Saint Vincent de Paul. His academic interests include the study of understanding and practice of tolerance, the reception of Jagiellonian values and ideas, the teachings of John Paul II, the social doctrine of the Catholic Church, and the social and political thought. 